\begin{tabular}{|c|c|c|}
\hline \multirow{2}{*}{\multicolumn{2}{|c|}{\begin{tabular}{l|l} 
DE & DE GRUYTER \\
OPEN
\end{tabular}}} & ECONOMIC THEMES (2017) 55(3): 437-450 \\
\hline & & DOI 10.1515/ethemes-2017-0024 \\
\hline
\end{tabular}

\title{
A QUALITATIVE RESEARCH ON MEDICAL TOURISM POTENTIAL OF ALANYA/TURKEY IN THE CONCEPT OF INTERNATIONAL SERVICE TRADE *
}

\author{
Ata Kahveci \\ Alanya Alaaddin Keykubat University, Institute of Social Sciences, Department \\ of International Trade, Antalya, Turkey \\ 凹ata.kahveci@alanya.edu.tr / atakahveci@gmail.com \\ Ercüment Okutmuş \\ Alanya Alaaddin Keykubat University, Faculty of Business, Antalya, Turkey \\ $\bowtie$ ercokut@hotmail.com \\ UDC \\ 338.48 - \\ 6:615.8(560) \\ Original \\ scientific \\ paper

\begin{abstract}
Reverse movement of patients in search of cheaper medical treatment from developed countries to undeveloped countries caused the birth of new phenomenon called medical tourism. Moreover, increasing value of medical tourism market each year draws attention of countries that are aiming to increase their economic growth. In this regard, the potential of Alanya as a medical tourism destination has been tried to determine in this paper. Therefore, it can be said that, the main objective of this research is to determine medical tourism potential of Alanya by taking into account the strengths and weaknesses of the destination as well. For this purpose, face-to-face interviews were conducted with an expert from each hospital and the county health department in Alanya, then these were transcripted into word documents and analyzed with NVivo 8.0. Consequently, it has been found that medical tourism potential of Alanya consist of thirteen sub-factors, which are respectively "Workforce", "Climate", "Central Asian Countries", "Geographic Location", "Incentive Policies", "Price", "Facilitators", "Service Quality", "Accessibility", "Hospital Investments", "Technological Equipment", "Conjectural Situation" and "Vacation". It can be said that, Alanya can benefit from job creation potential, decreasing foreign currency deficit because of service export and spillover effect to other sectors like in other destinations by using its potential to take part in medical tourism.
\end{abstract}

* This paper is derived from a master thesis defended at Akdeniz University, Institute of Social Sciences, Department of International Trade. 
Received: 09.05.2017.

Accepted: 20.08.2017.
Keywords: Medical Tourism, Service Export, NVivo, Alanya, Turkey.

JEL classification: B17, F19, L89, Z39

\section{Introduction}

In the age of rapid globalisation, knowledge and technology have changed consumption habits. Patients used to travel from undeveloped countries to developed countries due to the lack of necessary technology, human resources and facilities. Easing the trade barriers, movement of capitals and the Internet which spread the information instantly to anywhere helped undeveloped countries to catch up with developed countries in terms of health care supply. Undeveloped and developing countries are endowed with qualified human resources, advanced technological devices and tourism facilities with competitive prices compared to the developed countries for supplying health care to the patients.

Reverse movement of patients, called as medical tourists, from developed countries to abroad has accelerated because of expensive treatment prices, long waiting lists, cheaper or more convenient airway transportation, currency exchange rate advantage and aging of baby boomers (Connell, 2006: 1094; Connell, 2013: 116). When medical tourists' average spending, which is ten times more than average tourists (Ministery of Health, 2013:26), is taken into account, it is obvious to see the potential contribution of this specific international service export type to regional stakeholders in medical tourism destinations and economy in general as a spillover effect. Therefore, medical tourism has been introduced as a rising niche market and in this study current status of medical tourism in Alanya has been evaluated with a qualitative research by using software programme NVivo 8.0

\section{Theoretical background}

Classification of service trade by World Trade Organization (WTO) under The General Agreement on Trade in Services (GATS) is four-pronged as Mode 1: Cross border trade, Mode 2: Consumption abroad, Mode 3: Commercial presence, Mode 4: Presence of natural persons. Mode 1 indicates services received from abroad through telecommunication or postal infrastructure as well as consultancy, market research reports, telemedical advice, etc. Mode 2 shows the consumed services by person outside of its country as a tourist, student or patient. Mode 3 shows the service provided in another country by foreign owned or controlled company (bank, hotel group, construction company, etc.). Mode 4 is applicable if service is provided by foreign national within another country as moving of health worker, consultant or employee of the supplier (WTO, 2017). Four modes of supply are illustrated in Figure 1 . Since the service should be consumed at the 
destination country, medical tourism, which is a specific and popular form of service trade, takes place under the Mode 2: Consumption Abroad.

Medical tourism is a subset of health tourism and it should only be used if medical tourists experience any medical intervention (Connel, 2006: 1094). After the literature review, it is seen that medical tourism has been defined as "Travel with the aim of improving one's health, medical tourism is an economic activity that entails trade in services and represents the splicing of at least two sectors: medicine and tourism" (Bookman \& Bookman, 2007: 1) or as "Where and when patients travel overseas often over considerable distances, to take advantage of medical treatment which are not available or easily accessible (in terms of costs and waiting time) at home" (Connell, 2011: 11). As it is underlined in the definitions, key factors in medical tourism are consuming services in the other country, price advantage and avoiding waiting time to obtain medical treatment. Growth in tourism, familiarity with other cultures and advances in transportation turned people who cannot get medical service in their home country into medical tourists.

Figure 1. International service trade and modes of supply

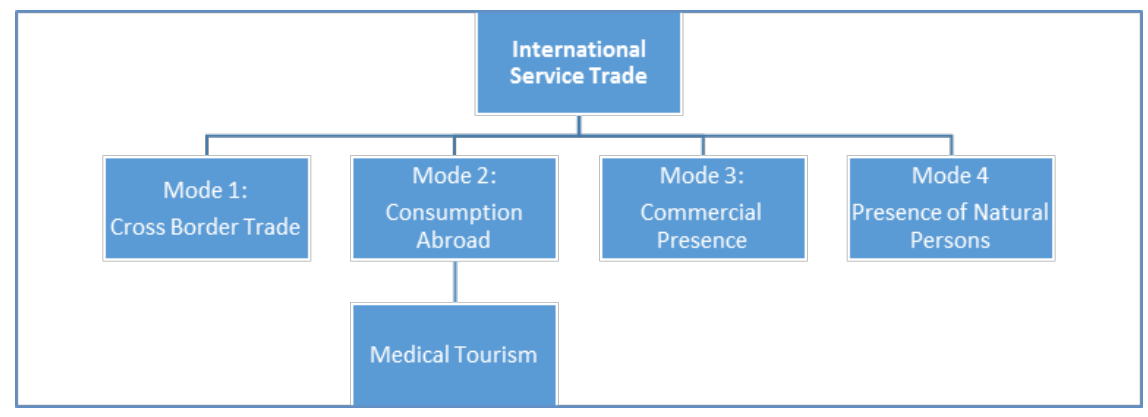

Source: Authors

Number of tourists traveling have grown from 529 million in 1995 to 1,235 million in 2016 (UNWTO, 2014: 11; UNWTO, 2017:12). Even though it is known that the trend increases every year, it is hard to find such a statistic for traveling medical tourists, since these statistics are kept differently by countries (Deloitte, 2011: 5-6). For example; 60,000 people travelled abroad to get medical treatment from England in 2010 (Pollard, 2012: 1), while this number was 750,000 during 2007 in USA (Deloitte: 2008: 3). When economic side of medical tourism evaluated, it is seen that total sector size was 79 billion dollars in 2010 and expected to reach 130 billion dollars in 2015 (www.nydailynews.com). However, new report says that 11 million people around the world, travelled abroad in search of medical services in 2015, while the medical tourism industry value was $\$ 439$ billion, and this value is expected to reach \$3 trillion by the year 2025 (www.ama.org). Consequently, countries take steps to channelise its sectors for maximising possible earnings, sustainable income, or share from medical tourism 
market. The factors that affect medical tourism should be analysed carefully in order to grow and understand the very nature of this market.

Globalisation accelerated the pace of medical tourism trend and after the literature review, it can be seen that nine key factor have an effect on the choice of people to be a medical tourist lay behind this trend. These factors are cost, waiting time, quality of health care, possible complications, technology, vacation, advances in transportation, confidentiality and cultural values.

Technology: Development in telecommunication technologies such as telediagnosis and teleanalysis reduced geographic barriers for cross border trade in medical services (Bookman \& Bookman, 2007: 4). Waiting Time: Obtaining a necessary treatment instantly in the USA may take months (Bies \& Zacharia, 2007: 1145), in Finland around 110 days in order to have simple cataract operation (OECD, 2013: 151) and that the waiting time can be reduced to days in medical tourism. Quality of Health Care: Organisations such as Accreditation Canada (Canada), Joint Commission International (USA), Japan Council for Quality (Japan), Health Care Accreditation (Jordan) etc. not only ensure the quality of healthcare in medical tourism (www.isqua.org) but also give medical tourists a chance to compare treatments abroad with the one at home. Cost: Price of treatment can vary, for example, a spine maroon transplantation costs $\$ 300.000$ in the USA, while it costs $\$ 40.000$ in India, $\$ 40.000-70.000$ in Turkey, $\$ 200.000$ in Switzerland (www.healthinturkey.org). Vacation: Buying a treatment package not only gives medical tourist a chance to vacation and travel but also getting to know exotic cultures (Yim, 2005). Advances in Transportation: Cheap travel options to far and remote destinations, speeded up the medical tourism trend (Bookman \& Bookman, 2007: 4). Confidentiality: Privacy and confidentiality are very important push factors for medical tourist in search of treatment or operations such as drug and alcohol rehabilitation, abortion or gender reassignment surgery (Connell, 2011: 47-48). Cultural Values: Language barriers and cultural differences are some barriers that may disturb medical tourists during operation. Today, health care suppliers have translators in many languages and also are more sensitive to cultural or religious differences, such as pork meat for Muslims etc. (Liu \& Chen, 2013: 79-82). Possible Complications: One of the reasons why complications occur is that medical tourist demand too many operation in a short time even though doctors advise not to do so (Herrick, 2007, 18-19). After the operation follow up care is another complication in medical tourism (Bies \& Zacharia, 2007: 50-51).

Turkey is natural and cultural hub since it is located in a peninsula which is at the crossroad of Europe, Asia and Africa and also known as a cradle of civilisation. Due to its unique history that Hattis, Hittites, Carians, Lelegians Phrygians, Urartians, Lycians, Lydians, Ionians, Persians, Macedonians, Romans, Byzantines, Seljuks, and Ottomans have made important contributions (www.turkeytourism.com), natural beauties, archeological sites and welcoming 
culture, Turkey is fascinating and easily accessible travel destination for tourists. Although offering different options, Turkey is still known as a summer destination since it offers quality and cheap services and sandy and long coastlines. Turkey tries to use its full potential to diversify its tourism supply in world tourism market and medical tourism is stated as an important alternative that could support this target. Alanya, which is located at the south coast of Turkey, as a famous summer resort has been using some practices in order to get its position in the medical tourism market. The city hosts nearly three million tourists every year and also more than twenty-thousand second home owners mainly from Northern Europe. Due to the importance of the medical tourism and the effort of Alanya for being a medical tourism destination, in this study we tried to examine medical tourism potential in Alanya

\section{Materials and methods}

Numerical values are important in quantitative research methods but when the sample or the subject is specific, qualitative research methods can be chosen instead of quantitative research methods. Since there are only five hospitals and a county health department in Alanya, qualitative research method were used in the conducted research for measuring the medical tourism potential in Alanya. Detailed information about experts and hospitals are given in Table 1 below.

Table 1. Interviewed hospitals and managers

\begin{tabular}{|l|c|c|c|c|c|c|}
\hline \multicolumn{1}{|c|}{$\begin{array}{c}\text { Demographics / } \\
\text { Experts }\end{array}$} & Expert1 & Expert2 & Expert3 & Expert4 & Expert5 & Expert6 \\
\hline Sex & Male & Female & Male & Male & Male & Male \\
\hline $\begin{array}{l}\text { Company in Business } \\
\text { for (years) }\end{array}$ & $6+$ & $1-3$ & $4-6$ & $1-3$ & $6+$ & $6+$ \\
\hline $\begin{array}{l}\text { Employed in the } \\
\text { Company (years) }\end{array}$ & $4-6$ & $1-3$ & $6+$ & $1-3$ & $1-3$ & $4-6$ \\
\hline Marital Status & Married & Married & Married & Married & Married & Married \\
\hline Position & Manager & $\begin{array}{c}\text { Finance } \\
\text { Manager }\end{array}$ & $\begin{array}{c}\text { Manager of } \\
\text { International } \\
\text { Patient } \\
\text { Department }\end{array}$ & $\begin{array}{c}\text { Manager of } \\
\text { International } \\
\text { Patient } \\
\text { Department }\end{array}$ & $\begin{array}{c}\text { Manager of } \\
\text { County } \\
\text { Health } \\
\text { Department }\end{array}$ & $\begin{array}{c}\text { Chief of } \\
\text { Staff } \\
\text { Doctor) }\end{array}$ \\
\hline Staff Number & 380 & 8 & 514 & 400 & - & 160 \\
\hline $\begin{array}{l}\text { Working in the } \\
\text { Sector for (years) }\end{array}$ & $6+$ & $6+$ & $4-6$ & $1-3$ & $4-6$ & $6+$ \\
\hline $\begin{array}{l}\text { Share of Medical } \\
\text { Tourism in Total } \\
\text { Revenue }\end{array}$ & - & $25 \%$ & - & $10 \%$ & - & $50 \%$ \\
\hline Age & $42-49$ & $34-41$ & $42-49$ & $26-33$ & $42-49$ & $42-49$ \\
\hline Bed Capacity & 84 & - & 120 & 150 & - & 78 \\
\hline
\end{tabular}

In order to get detailed information from each expert, in depth interviews were conducted face-to-face and recorded to a digital device and then transcripted into 
written format in a word document. This data were analysed with NVivo 8.0 which helps researchers to classify the qualitative data systematically. In NVivo programme, classification is called as Tree Nodes. The outcome of this process is the models given by NVivo 8.0 according to the classification of subcategories. In the model, the size of circles and "Parent" are given randomly by NVivo, so they are irrelevant and do not refer any specific meaning. However, the little blue circle surrounded by the three green circles in each sub-factor indicates that this model is the outcome of the NVivo, not made in any other programme.

\section{Results and discussions}

Defining the endowed factors or strengths of Alanya is essential in order to shed light on the actual potential. In this sense, opinions of experts about the region analysed by NVivo 8.0 are given in a model below.

Figure 2. Model of medical tourism potential in Alanya

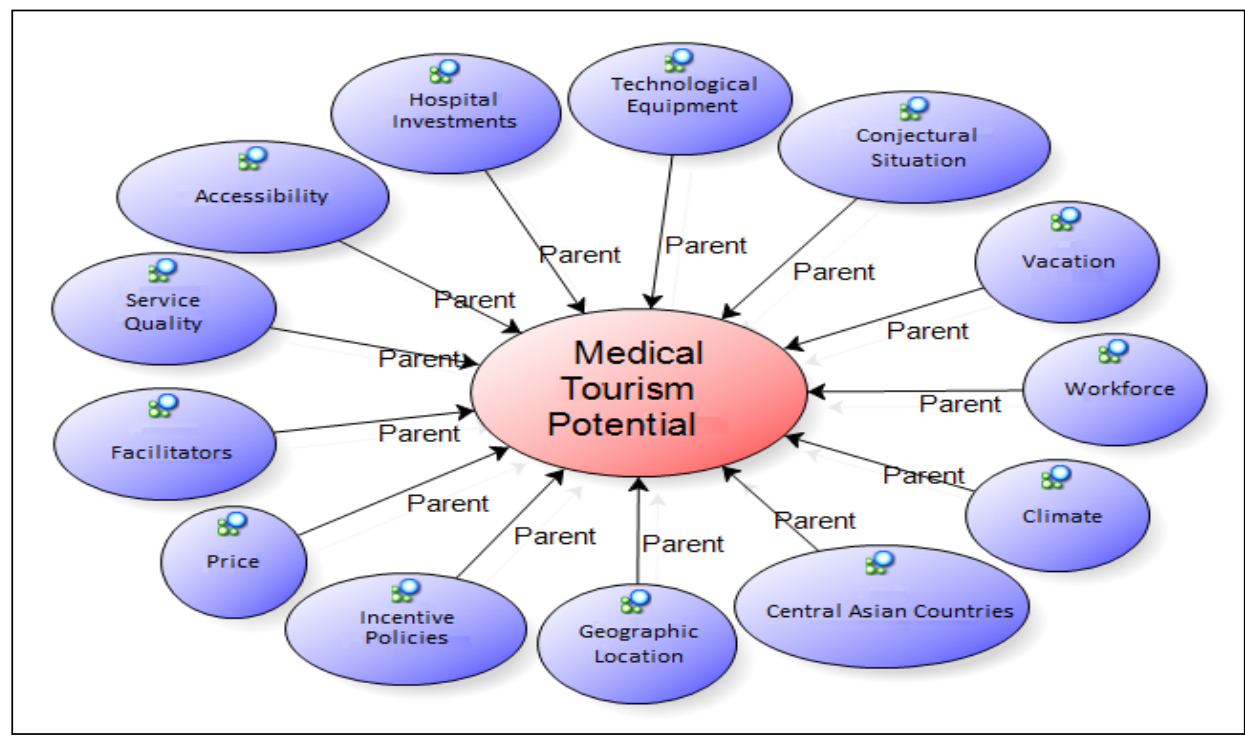

Source: Authors

As it can be seen from Figure 2 above, there are 13 subfactors affecting the medical tourism potential in Alanya. These are respectively; "Workforce", "Climate”, "Central Asian Countries”, "Geographic Location”, "Incentive Policies”, "Price”, "Facilitators”, "Service Quality”, “Accessibility”, "Hospital Investments”, "Technological Equipment”, “Conjectural Situation” and "Vacation”.

Workforce: Expert6 made an emphasis on education and quality of workforce, while Expert5 mentioned that workforce could be employed easily if medical tourism 
facilities were expanded. Furthermore, Turkey has young workforce that can support medical tourism directly.

Climate: Expert3 said that one of the motivations for medical tourists to choose Alanya as medical tourism destination were 300 sunny days in a year. At this point, Alanya can be chosen only because of the climate when compared with the other destinations with cold weather.

Vacation: Expert2 and Expert5 said that medical tourists could reach medical treatment and enjoy their vacation at one of the most attractive and well-known tourism destinations in Turkey. Medical tourists and their companions can easily find comfortable accommodation among many options since Alanya offers thousands of bed capacity and significant number of five star hotels.

Central Asian Countries: Expert1 said that the efforts of the Turkish government might have a positive effect on Turkey's medical tourism potential. In addition to that, it can be said that cultural and religious similarities might have a positive effect on that.

Geographic Location: Expert3 and Expert6 said that medical tourists in Asia, Europe and the Middle East preferred Turkey since it is at the crossroad of three continents. Expert3 stated that geographic location of Turkey also meant shorter travel duration for medical tourists, which might be an important factor for choosing Turkey. Moreover, closeness to Gazipaşa Airport and Antalya Airport is another factor that will affect medical tourism demand to Alanya.

Incentive Policies: Expert1 stated that incentives were given for encouraging and channelising entrepreneurs to the medical tourism industry. Since incentives reduce costs, businesses benefited from incentives will have price advantage among regional and international competitors.

Price: Expert3 said that Turkey had comparative advantage on treatment prices for now. Since price is the reason why medical tourism started, reasonable price helps destinations to increase their medical tourism potential.

Facilitators: Expert4 stated that these firms were not only intermediaries but also trusted councilors for medical tourists for choosing a medical tourism destination. Alanya has been a popular destination for tour operators and agencies in the tourism industry for many years. Extending working area and upgrading marketing mix are another important point for increasing medical tourism potential.

Service Quality: Expert3, Expert4, Expert5 and Expert6 pointed out that public and private hospitals in Turkey provided good healthcare services and especially the quality of healthcare services in private hospitals can be identified as luxury or excellent. In addition to this, four hospitals in Alanya are capable of doing bypass operations and this is an important indicator for service quality. On the other hand, not having any international accreditation such as JCI is an important weakness for 
medical tourism development in Alanya. If these hospitals want to get a share from the medical tourism market, they should start planning their marketing mix accordingly and most importantly should get international accreditations according to their target markets.

Accessibility: Expert3 mentioned that accessibility had a significant impact on the medical tourism growth such as İstanbul. Since Alanya is located between Gazipaşa Airport and Antalya Airport and number of direct flights to those airports increased, Alanya might be seen as an accessible and attractive destination for medical tourists.

Hospital Investments: Expert6 emphasised the necessity of investments to be extended and upgraded by service providers and Expert4 mentioned seven city hospitals to be invested in Turkey.

Technological Equipment: Expert3 said that Alanya had three tomographs while Georgia has none and this is an indicator for technological equipment infrastructure level in Alanya. Expert6 said that Turkey is only good in diagnose and treatment but not in developing the health related technologies or technological devices. Expert2 stated that when they checked patients from developed countries like Germany, technological devices are not used as public thinks. Advanced technological devices can be found in all the hospitals in Alanya and this is an indicator for good technological equipment level.

Figure 3. Model of advantages in medical tourism

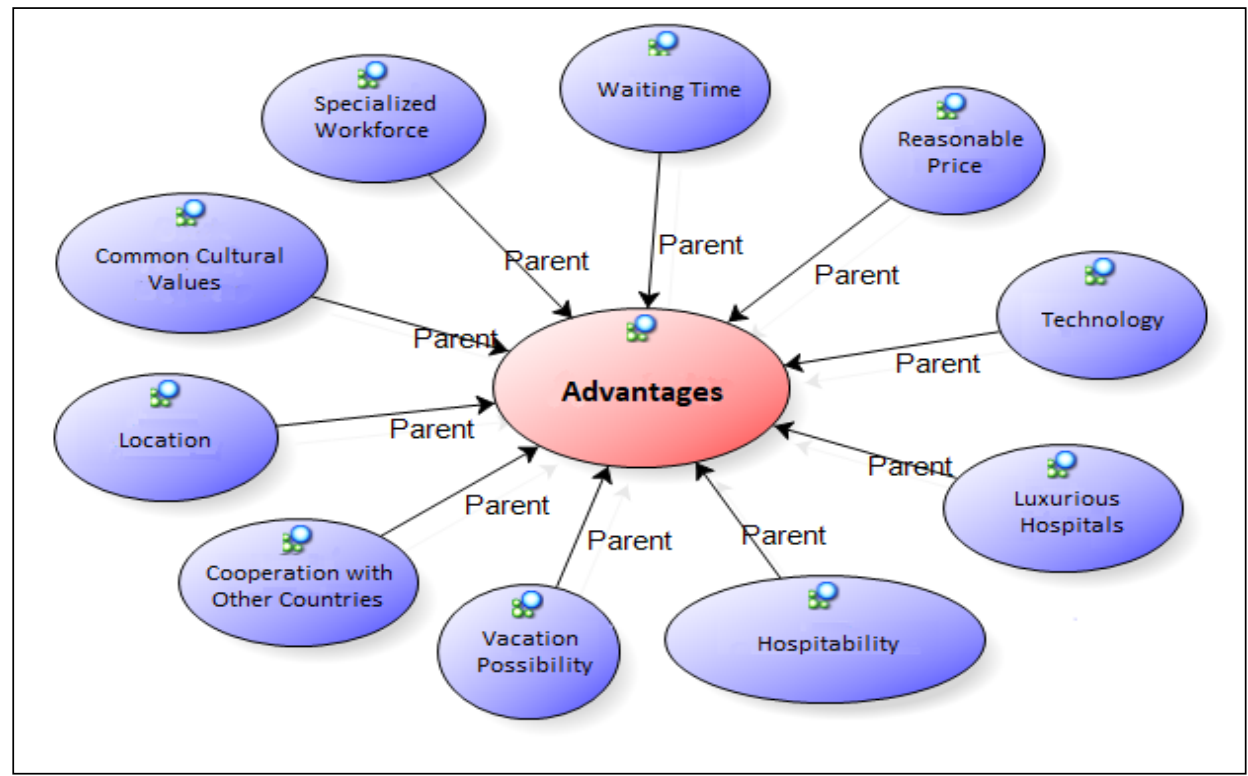

Source: Authors 
Conjectural Situation: Expert3 said that during the incidents happened in Libya, medical tourists decided to change their route to Turkey and the country benefited from conjectural change in the region. Furthermore, Expert6 said that Turkey should build good relations with its neighbours and developed countries in order to reach its medical tourism goals. Since politic and economic instability in a country affect others in the region, countries dealing with medical tourism should be careful in their politics and foreign relations. For example, Turkey had many medical tourists from Libya and Iraq during the war in Libya.

As it can be seen from Figure 3 above, the advantages of medical tourism in Alanya consist of 10 subfactors. These are respectively; "Waiting Time", "Reasonable Price”, "Technology”, "Luxurious Hospitals”, "Hospitability”, "Vacation Possibility", "Cooperation with Other Countries", "Location”, "Common Cultural Values" and "Specialised Workforce".

Waiting Time: Expert6 stated that waiting time had a crucial impact on medical tourists' decisions to choose Turkey as a medical tourism destination.

Reasonable Price: Expert4 said that Turkey had reasonable prices in accommodation, transfer, medicine and other services.

Technology: Expert2 and Expert6 said that Turkey was better than its rivals in terms of technological equipment. Expert3 supported this opinion by saying there is no tomography in Georgia, while there are 3 just in Alanya.

Luxurious Hospitals: Expert4 said private hospitals were better than state hospitals in terms of service quality in Alanya. Expert3 said that an insurance company from Holland told them how luxurious their hospital was and they negotiated about the cost of treatments.

Hospitability: Expert5 made an emphasis on the word hospitability and Expert3 stated that their international patients told them how nice they were welcomed as patients in Turkey when compared to other countries.

Vacation Possibility: Expert2 and Expert5 said that medical tourists could enjoy touristic sites and vacation facilities, while having treatment. Expert4 said that vacation options could vary from sea, sand and sun to culture and winter sports.

Cooperation with Other Countries: Expert2 stated that if requested, they also would accept medical tourists by getting in contact with partner hospitals in medical tourists' country and handle pre-diagnosis, roentgen etc. and afterwards they negotiate treatment and price.

Location: Expert3 made a special emphasis on the location of Turkey and said that a hospital with latest technology and good doctors in Ireland was closed and only reason for that was the lack of direct flight to the destination. 
Common Cultural Values: Expert5 pointed out the historical and cultural closeness of Turkey with different regions and countries as another advantage.

Specialized Workforce: Expert5 and Expert2 said that Turkey has many experienced doctors and nurses, especially in the surgeries need delicate operations.

As it can be seen from Figure 4, disadvantages of medical tourism in Alanya consist of 13 subfactors. These are respectively; "Payment Issues", "Short Treatment Duration”, "Lack of Specialised Workforce”, "Deception and Diversion”, "Bad Price Policy”, "Unspecialised Enterprises”, "Foreign Language”, "Legal Issues”, "Negative Country Image”, "Lack of Cooperation”, “Tourist Health”, "Infrastructure Issues" and "Promotion".

Figure 4. Model of disadvantages in medical tourism

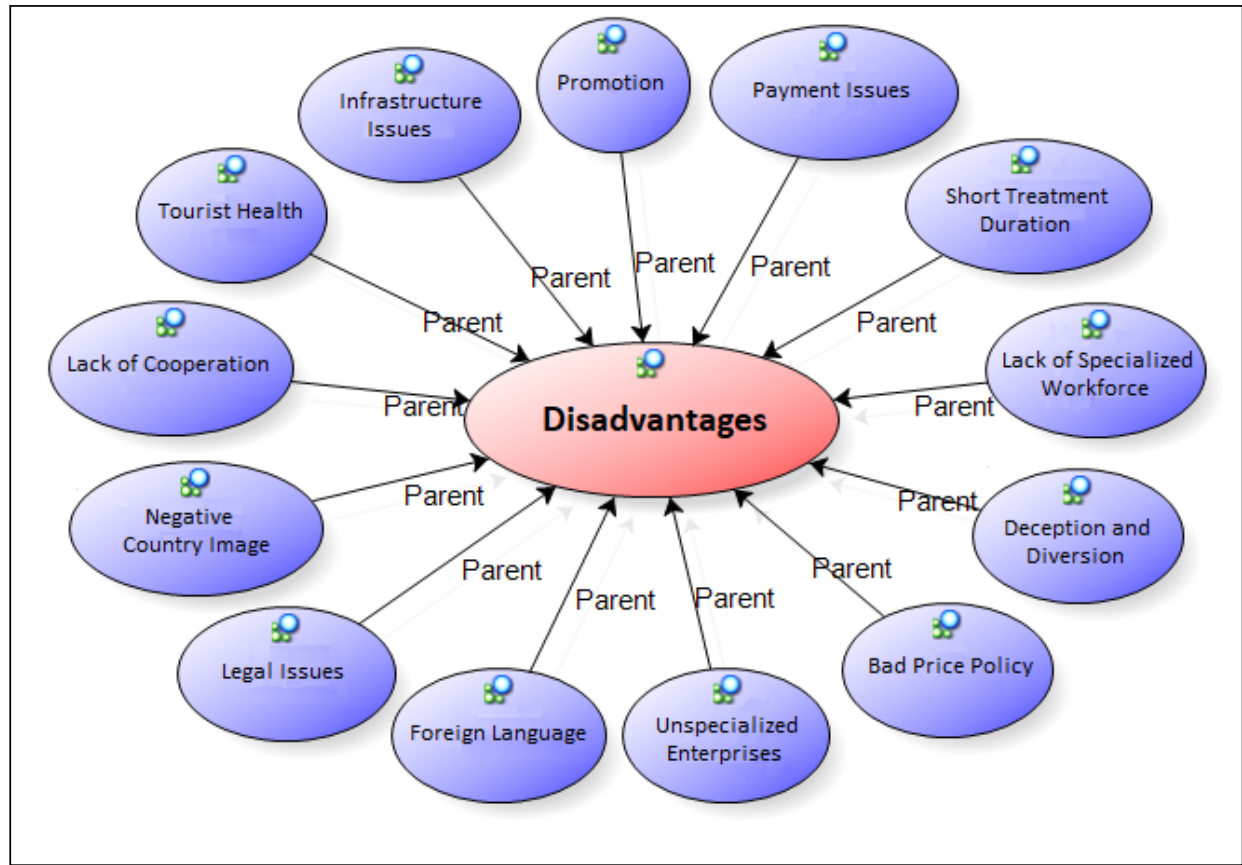

Source: Authors

Payment Issues: Some of the hospitals are facing payment issues after the treatment but Expert2 and Expert4 pointed out the payment policies of hospitals as the reason for that issue. According to Expert3 hospitals that ask prepayment before the procedure do not face such problem.

Short Treatment Duration: Expert2 says that medical tourists ask for getting whole treatment done in a short time such as 15 days even though doctors' warnings. 
Lack of Specialised Workforce: Expert4 stated that there is a high demand for aesthetic and plastic surgery, but in Antalya region we only have 3 or 4 doctors working on that specific area.

Deception and Diversion: Expert2 pointed out that some agencies only focued on the current year's profit or earnings, and sometimes attempting to deceive the medical tourists after they brought them into Turkey for treatment and charge more money than they agreed.

Bad Price Policy: Expert3 stated that competition in medical tourism sector based only discount in price and this has negative effect on all shareholders.

Unspecialised Enterprises: Expert3 said one of the main problems in medical tourism were intermediaries, which are mushroomed, moreover they had no expertise or knowledge in this unique and complicated field.

Foreign Language: Expert3 said that they employ personnel according to their foreign language abilities. Besides, Expert5 stated that a lack of personnel with foreign language skills in public hospitals is another problem.

Legal Issues: Expert4 pointed out the lack of regulation in the medical tourism sector.

Negative Country Image: Expert1, Expert2 and Expert4 emphasised that perceived image of Turkey by other countries was negative and it caused difficulties in attracting medical tourist.

Lack of Cooperation: While Expert5 pointed out the lack of integrated coordination among health, marketing and transportation, Expert4 added collaboration problem between hospitals.

Tourist Health: Expert5 and Expert4 stated that since hospitals were located in a touristic destination, they generally focused on health of tourists and neglect giving enough importance to medical tourism.

Infrastructure Issues: Expert4 stated infrastructure in Turkey is inadequate when compared with Europe and Dubai. In addition to this, Expert5 indicated government hospitals in Turkey are not totally ready for medical tourism.

Promotion: Expert3 said that medical tourism sector did not exactly know how to reach right markets and also government promotion activities were inefficient.

\section{Conclusion}

It is predicted that the size of the medical tourism sector would reach three billion US $\$$ by the year of 2025 according to the forecasts. Medical tourism destinations should determine their potentials and develop strategies accordingly for gaining a share from this huge market. In order to do that, face-to-face interviews with 
experts in Alanya analysed with NVivo in this study. It has been found that the medical tourism potential of Alanya consists of thirteen subfactors, which are respectively "Workforce", "Climate", "Central Asian Countries", "Geographic Location”, "Incentive Policies”, "Price”, "Facilitators", "Service Quality", "Accessibility”, "Hospital Investments”, "Technological Equipment”, "Conjectural Situation" and "Vacation". The advantages of medical tourism in Alanya consist of 10 sub-factors, which are "Waiting Time", "Reasonable Price", "Technology", "Luxurious Hospitals", "Hospitability”, "Vacation Possibility”, "Cooperation with Other Countries", "Location", "Common Cultural Values" and "Specialised Workforce". Disadvantages of medical tourism in Alanya consist of 13 subfactors, which are "Payment Issues", "Short Treatment Duration", "Lack of Specialised Workforce", "Deception and Diversion", "Bad Price Policy", "Unspecialised Enterprises”, "Foreign Language”, "Legal Issues”, "Negative Country Image”, "Lack of Cooperation”, "Tourist Health”, "Infrastructure Issues” and "Promotion”.

Relatively reasonable prices, climate, location at the seaside, closeness to airports, familiarity of tour operators in the region and accommodation options in five star hotels in Alanya are important factors in decision making process for medical tourists. Advanced technological equipment in hospitals, young workforce that can be employed easily and government incentives for medical tourism are other factors that determine the quality of supplied services and its price and cost. Marketing strategy should be based on these factors since these are the strength of Alanya. In addition, cultural similarities with Central Asian Countries and religious similarities also should be used in the marketing of medical tourism. However, one of the weaknesses at this point is the lack of international accreditations such as JCI. When the accreditation is completed, medical tourists can compare the quality of services at the destination with the internationally accepted standards. Last but most importantly, the importance of politic and economic stability should not be forgotten because it can surpass any other aforementioned condition for being successful in medical tourism. Since tourism is sensitive to safety and security issues, any mistake in politic or foreign relations can directly surpass all the other positive factors as experienced in Libya, Iraq and Iran before. In this regard, Alanya can extend its medical tourism potential by managing and harmonising the cooperation between state institutions and the private sector.

In this study, medical tourism, which has recently emerged and rapidly developing new tourism niche has been examined and its potential in Alanya has tried to be determined. Taking into account the findings of this study would be helpful and beneficial for public and private hospitals as well as other institutions interested in medical tourism in Alanya. In the future studies, academicians would extend the medical tourism literature by examining medical tourism potentials in different destinations and medical tourism performance of destinations. 


\section{References}

Bies W. \& Zacharia L., (2007) Medical Tourism: Outsourcing Surgery. Mathematical and Computer Modelling, 46, 1144-1159.

Bookman M.Z. \& Bookman K.R., (2007) Medical Tourism in Developing Countries. New York: Palgrave Macmillian.

Connell J., (2006) Medical Tourism: Sea, Sun, Sand and Surgery. Tourism Management, 27, 1093-1100

Connell J. (2011) Medical Tourism, Bodmin: Cabi.

Connell J., (2013) Medical Tourism in the Caribbean Islands: A Cure for Economies in Crisis?. Island Studies Journal, 8(1): 115-130.

Deloitte, (2008) Medical Tourism. Consumers in Search of Value, Deloitte Center for Health Solutions, Washington DC.

Deloitte, (2011) Medical Tourism in Australia: A Scoping Study, Department of Resources, Energy and Tourism, Deloitte, 15 August 2011, https://www.austrade.gov.au/ArticleDocuments/5499/MedicalTourismreport_Final.p df.aspx (15.08.2017).

Herrick D.M. (2007) Medical Tourism: Global Competition in Health Care, National Center for Policy Analysis (NCPA), Policy Report No:304, Dallas, Texas.

Liu C. \& Chen C., (2013) Cultural Issues in Medical Tourism. American Journal of Tourism Research, 2(1): 78-83.

Ministry of Health (2013) Türkiye Medikal Turizmi Değerlendirme Raporu 2013, T.C. Sağllk Bakanlı̆̆ı Sağlık Hizmetleri Genel Müdürlüğ̈̈ Sağllk Turizmi Daire Başkanlığı, http://www.saglikturizmi.org.tr/yonetim/templates/addons/ckfinder/ userfiles/TMTD_2013_raporu.pdf (14.08.2017).

OECD, (2013) Health at a Glance 2013: OECD Indicators. OECD Publishing, http://dx.doi.org/10.1787/health_glance-2013-en (14.08.2017).

Pollard K., Medical Tourism: Key Facts, (www.treatmentabroad.com); http://intuitionconnect.com/asset_files/Medical\%20Tourism\%20Fact\%20Sheet_0.pd $\underline{\mathrm{f}}(13.08 .2017)$.

UNWTO, (2014) UNWTO Annual Report 2013. World Tourism Organization (UNWTO), Madrid, Spain.

UNWTO, (2017) UNWTO Annual Report 2016. World Tourism Organization (UNWTO), Madrid, Spain.

Yim C.K. (2005) Healthcare Destinations in Asia. Hong Kong: Asia Case Research Center.

WTO, https://www.wto.org/english/tratop_e/serv_e/cbt_course_e/c1s3p1_e.htm (14.08.2017).

https://www.ama.org/publications/eNewsletters/MHSNewsletter/Pages/visa-says-medicaltourism-will-reach-\$3-trillion-by-2025.aspx (13.08.2017)

http://www.turkeytourism.com/why_turkey_tourism_holiday.html (13.08.2017)

http://www.healthinturkey.org/en-EN/Price.aspx (22.06.2016).

http://www.isqua.org/accreditation/accredited-organisations-standards (22.06.2016).

http://www.nydailynews.com/life-style/health/medical-tourism-sets-pulses-racing-millionpatients-medical-treatment-year-article-1.1081885 (18.08.2017). 


\section{KVALITATIVNO ISTRAŽIVANJE POTENCIJALA MEDICINSKOG TURIZMA U ALANJI}

Apstrakt: Povratno kretanje pacijenata u potrazi za jeftinijim lečenjem od razvijenih zemalja do nerazvijenih zemalja prouzrokovalo je nastanak nove pojave zvanog medicinski turizam. Štaviše, povećanje vrednosti tržišta medicinskog turizma svake godine privlači pažnju zemalja koje imaju za cilj povećanje njihovog ekonomskog rasta. $\mathrm{S}$ tim u vezi, u ovom radu pokušlo se utvrditi koji je potencijal Alanje kao destinacije za medicinski turizam. Intervjui licem u lice sa stručnjacima iz svake od bolnica i okružnog zdravstvenog odeljenja u Alanji dati su u pisanom dokumentu i analizirani sa NVivo 8.0. Shodno tome, potencijal za stvaranje novih radnih mesta, smanjenje deviznog deficita zbog izvoza usluga i efekta prelivanja na druge sektore, glavni su razlogi za učestvovanje destinacija u medicinskom turizmu. Shodno tome, utvrđeno je da se potencijal medicinskog turizma Alanje sastoji od trinaest podfaktora, koji su "radna snaga", "klima", "zemlje centralne Azije", "geografska lokacija", "podsticajne politike", "cena" "moderatori", "kvalitet usluga", "prisupačnost", "ulaganje u bolnice", "tehnološka oprema", "hipotetička situacija" i "godišnji odmor". Može se reći da Alanja ima koristi od potencijala za otvaranje novih radnih mesta, smanjujuci devizni deficit zbog izvoza usluga i efekta prelivanja na druge sektore kao i u drugim destinacijama, koristeći svoj potencijal da učestvuje u medicinskom turizmu..

Ključne reči: Medicinski turizam, izvoz usluga, NVivo, Alanja.

\section{Author's biographies}

Ata Kahveci is a PhD candidate at Institute of Social Sciences, Department of International Trade in Alanya Alaaddin Keykubat University, Turkey. He is also working as a researcher at Faculty of Business in Alanya Alaaddin Keykubat University. He has spent six months as part of his doctoral study in Lithuania. His research interests include international trade, logistics, cost accounting and medical tourism.

Ercüment Okutmuş is an Assistant Professor at the Faculty of Business in Alanya Alaaddin Keykubat University, Turkey. He obtained his $\mathrm{PhD}$ degree from the Faculty of Business at Afyon Kocatepe University (in the specific field of Accounting and Finance). His key research interests are contemporary cost methods, cost accounting, accounting and health tourism. 